\title{
Rевевки автіске: Coconut based cropping system with medicinal plants for sustainable production
}

\author{
M. PRABU, K. RAJAMANI AND N. CHEZHIYAN
}

Article Chronicle : Received : 14.07.2017;

Accepted : 29.07.2017

\section{KeY Words:}

Intercropping, Coconut, Medicinal plants, Plant height, Plant yield, BCR

\section{Author for correspondence :}

\section{PRABU}

Horticultural College and Research Institute, Tamil Nadu Agricultural University, COIMBATORE (T.N.) INDIA

See end of the article for authors' affiliations
SUMMARY : Coconut based cropping system ensures maximum resource utilization, improvement in the soil properties and biological activities leading to better growth and higher additional return from per unit area of land. Coconut plant is eulogized as karpavriksha or tree of garden. In the recent past economy of coconut farmer's had weakened due to the fluctuation in the price of coconut. So, adoption of coconut based multiple cropping system can improve the economic status of the farmers. The experiment was carried out in a 25 year old coconut plantation at farmer's field Coimbatore, Tamil Nadu,to identify suitable medicinal plants for intercropping in coconut gardens of maidan tract of Tamil Nadu. The medicinal plants selected for intercropping were Aloe, Arrow root, Ashwagandha, glorylily, kalmegh, periwinkle, Tulsi. Intercropping dynamics of the coconut based farming of these medicinal plants were worked out by using the parameter viz., plant height $(\mathrm{cm})$ / Vine length / Plant spread, number of branches / Sucker/no. of primary vines, no. of leaves,Individual plant yield, Tuber/Rhizome/ Sucker yield. The BCR worked for the crops revealed that the intercropping system of growing Periwinkle under coconut was recorded the highest net income (Rs. 81,865/ha) and BC ratio (2.79) followed by tulsi (Rs. 77,472/ha and 2.71), kalmegh (Rs. 75,163/ha and 2.56), arrow root (Rs. 72,211/ha and 2.28), Aloe (Rs. 71,865/ha and 2.39), Ashwagandha, (Rs. 67,058/ha and 2.68).Beneficial effect of intercropping on main crop i.e. coconut was observed which was reflected in the yield. Hence, intercropping of periwinkle,Tulsi, kalmegh, aloe, arrow root, with coconut can be recommended for maidan tract of Tamil Nadu.

How to cite this article : Prabu, M., Rajamani, K. and Chezhiyan, N. (2017). Coconut based cropping system with medicinal plants for sustainable production. Agric. Update, 12 (TECHSEAR-4): 1122-1125; DOI: 10.15740/ HAS/AU/12.TECHSEAR (4)2017/1122-1125. 